\title{
TRADISI “ NYARE DHINA" DALAM PENENTUAN HARI PERNIKAHAN PERSPEKTIF HUKUM ISLAM DI DESA LARANGAN BADUNG
}

\author{
Sirojuddin, dan Mohammad Bashri Asyari \\ Jurusan Syari'ah dan Ekonomi STAIN Pamekasan, jln. Pahlawan \\ KM. 04 Pamekasan
}

\begin{abstract}
Abstrak:
Tradisi nyare dhina yang berkembang dalam masyarakat Larangan Badung adalah sebagai awal dari perencanaan penentuan, baik hari atau bulan untuk melangsungkan acara pernikahan yang biasanya dalam masyarakat Larangan Badung, akad nikah serta walimah dilaksanakan dalam satu waktu. Kebiasaan masyarakat Larangan Badung dalam tradisi nyare dhina mempunyai harapan dengan melaksanakan hari pernikahan di hari yang baik yakni meminta petunjuk pada Kyai maka akan memperoleh kebaikan bagi kedua mempelai yang melangsungkan pernikahan, sebagaimana harapan banyak orang dalam bentuk keluarga yang Sakinah Mawaddah Warahmah serta keturunan shaleh shalehah yang akan mereka didik nantinya.
\end{abstract}

\section{Kata Kunci:}

Pernikahan, nyare dhina, Tradisi

\section{Pendahuluan}

Diantara salah satu kesempurnaan seseorang yang beriman adalah dengan menikah. Ada begitu banyak hikmah yang terkandung dalam pernikahan, seperti akan terjalin rasa cinta dan kasih sayang, saling menjaga dan melindungi, serta lahirnya generasi-generasi penerus kehidupan. Dan dengan menikah, maka nafsu syahwat akan terpelihara, seperti yang 
ditunjukkan dalam salah satu Hadits Rosulullah SAW, beliau menganjurkan untuk kawin dalam sabdanya yang diriwayatkan oleh Anas bin Malik R.A: Sesungguhnya Nabi SAW bersabada, mengapa orang-orang mengatakan begini dan begitu, padahal aku sholat dan aku juga tidur,berpuasa juga berbuka dan aku juga menikahi perempuan, jadi barang siapa yang menbenci ajaranku dia bukan termasuk golonganku. ${ }^{1}$

Pernikahan dalam kehidupan masyarakat desa, pada umumnya masih melestarikan tradisi dan budaya. Salah satunya adalah dalam menentukan hari baik dengan sebutan "nyare dhina" yang dalam bahasa Indonesia dikenal dengan hari baik dalam penentuan hari pernikahan. Apabila calon suami dan calon istri akan melangsungkan pernikahan, maka keluarga dari kedua belah pihak akan menentukan hari " $\mathrm{H}$ " atau hari dilaksanakannya akad nikah. Kebiasaan yang dilakukan masyarakat Larangan Badung dalam menentukan hari " $\mathrm{H}$ " ini adalah kedua belah pihak keluarga mengadakan silaturrohim khusus untuk memilih harinya. Dan calon mempelai beserta orang tua masing-masing sudah mempunyai kesamaan tujuan tentang pemilihan hari atau bulan apa yang terbaik, namun yang lebih dominan dalam hal ini ditentukan oleh keluarga mempelai perempuan.

Dalam acara akad nikah yang sakral ini, maka acara akad tersebut akan dilaksanakan dengan sebaik-baiknya. Sebelum mendatangi Kyai, masyarakat biasanya lebih dulu ke sesepuh (orang yang paling tua dan dianggap "tahu"), dengan tujuan nyare dhina. Harapannya adalah kedua mempelai akan memperoleh kebaikan-kebaikan setelah menikah. Dan apabila pada suatu hari memperoleh keburukan dalam rumah tangganya, mereka tidak akan merasa bersalah, karena sudah didahului dengan ikhtiyar atau usaha nyare dhina, dalam istilah madura dikenal dengan "ngadhedhi" dan kemudian pasrah atas kehendak Allah.

${ }^{1}$ Ibnu Hajar al-'Asqalânî, Bulûgh al-Marâm, (Surabaya: Nurul Hidayah, t.t), hlm. 208. 
Pada dasarnya, mencari waktu yang baik atau yang terbaik bukanlah sesuatu yang disyaratkan dalam setiap melangsungkan akad nikah. Namun dalam tradisi masyarakat Larangan Badung, bahwa menentukan hari dalam akad nikah adalah sesuatu yang tidak dapat begitu saja dilewatkan. Masyarakat Larangan Badung mempercayai nyare dhina adalah media mencari berkah Allah dalam pelaksanaan akad nikah untuk kebahagian kedua pasangan, sehingga nyare dhina oleh masyarakat tidak dapat dihilangkan dan terus dilestarikan secara turun temurun.

Akan tetapi, banyak Referensi yang membahas dan memberi tuntunan praktis dalam nyare dhina, yang tentunya tidak menjamin akan kebenaran dalam pandangan hukum Islam, seperti halnya melalui Paranormal, dan Primbon. Masyarakat Larangan Badung menjalankan tradisi nyare dhina sebatas taqlid, ${ }^{2}$ mereka berpedoman pada buku-buku klasik seperti primbon, atau mereka benar-benar mencari keberkahan sehingga Kyai atau orang 'Alim dalam menentukan dhina.

Tidak ada ayat atau hadist shahih yang secara khusus memerintahkan atau mengkhususkan hari-hari tertentu untuk melaksanakan akad nikah. Banyak hadits yang menjelaskan keistimewaan beberapa hari diantara tujuh hari, dan bulanbulan diantara dua belas bulan, sehingga dapat di jadikan pedoman dan rujukan dalam menentukan hari akad nikah. Sebagaimana pendapat para ulama' tentang empat bulan yang dimuliakan Allah (asyahrul hurum) seperti bulan Muharram, Dzulhijjah, Dzulqo'dah, dan Rajab.

Seperti hari senin, merujuk pada kelahiran Rasulullah Muhammad, tidak ada dalil yang menerangkan kebaikan hari tersebut sebagai anjuran melaksanakan pernikahan. Meskipun

\footnotetext{
2 Taqlid adalah menerima perkataan orang lain yang berkata, dan kamu tidak mengetahui alasan perkataan itu. A. Basiq Djalil, Ilmu Ushul Fiqih 1 dan 2 (Jakarta: Kencana, 2010), hlm. 195.
} 
demikian dengan adanya kesamaan hari itu diharapkan kebaikan juga akan diperoleh kedua pasangan tersebut.

Dari uraian di atas sebagai asumsi yang tidak diketahui apa dampak dari penentuan hari tersebut para ulama menyebut hal ini yang disebut dengan tafaul. ${ }^{3}$ Semuanya kembali kepada keyakinan masing-masing dengan didasari Iman, maka Allah akan memberi kebaikan. Pada jaman dahulu bangsa Arab mengenal tentang hari baik dan hari yang tidak baik atau dikenal dengan hari (na'as) yakni bulan Syawal. Sehingga pada masa tersebut, bulan Syawal sangat dihindari dalam melaksanakan perkawinan. Pada masa itu Sitti Aisyah r.a selaku istri Rasulullah berkata: Rasulullah SAW mengawini aku pada bulan Syawal, dan tinggal bersamaku pada bulan Syawal, karenanya Sitti Aisyah menganjurkan kaum muslim untuk menggauli istrinya di bulan Syawal. ${ }^{4}$

Dengan riwayat tersebut Sitti Aisyah ingin meluruskan asumsi masyarakat Arab yang menghindari bulan Syawal untuk melaksanakan pernikahan, bahkan menganjurkannya. Adapun kebiasaan masyarakat Larangan Badung dalam melaksanakan akad nikah menggabungkan acaranya dengan walimah, sehingga yang menjadi saksi akad nikah adalah semua undangan yang hadir dalam walimah tersebut. Sedangkan hari yang umum digunakan masyarakat Larangan Badung adalah hari Senin, Kamis dan Jumat. Namun, sepengetahuan peneliti, yang lebih sering dilakukan dalam nyare dhina adalah bulan Syawal, Sya'ban, dan Dzulhijjah untuk melaksanakan akad serta Walimah tersebut. Berangkat dari gambaran yang telah diuraikan dalam latar belakang masalah di atas, maka pokok masalah yang akan dibahas dalam Penelitian adalah: (1) Bagaimana Tradisi "nyare dhina" dalam penentuan hari pernikahan di Desa Larangan Badung

3 Tafaul adalah doa yang tidak diucapkan dalam artian do'a yang di simbolkan dengan suatu tindakan.

4 Maulana Muhammad Zakariya al-Kandahlâwî, Fadilah al-A'mâl, terj. Musthafa Sayani, (Bandung: Pustaka Ramadhan, t.t), hlm. 575. 
Kecamatan Palengaan Kabupaten Pamekasan. (2) Faktor apa saja yang melatarbelakangi Tradisi "nyare dhina" dalam penentuan hari pernikahan di Desa Larangan Badung Kecamatan Palengaan Kabupaten Pamekasan. (3) Bagaimana Perspektif Hukum Islam tentang Tradisi "nyare dhina" dalam penentuan hari pernikahan di Desa Larangan Badung Kecamatan Palengaan Kabupaten Pamekasan.

\section{Proses Timbulnya Tradisi}

Tradisi yang ada dalam masyarakat tidak terhitung jumlahnya, akan tetapi kebanyakan timbul dari sebab-sebab yang ada di masyarakat tergantung kondisi dan dinamika yang terjadi. Ada kalanya tradisi yang berjalan tidak berdasarkan kebutuhan, tetapi lebih karena warisan dari orang-orang sebelumnya. Sebagaimana yang tertera dalam surat al-Zuhruf, Ayat 22: "Bahkan mereka berkata, sesungguhnya kami mendapati nenek moyang kami menganut suatu agama, dan kami dapat petunjuk untuk mengikuti jejak mereka". ${ }^{5}$

Tradisi yang telah ada dalam masyarakat akan mengakar dan mempengaruhi mental pribadi masyarakat, yang pada akhirnya mereka akan terus menjaga dan melestarikan tradisi tersebut. Dan tradisi akan dianggap sebagai kebutuhan primer dalam kehidupan sehari-hari, meskipun banyak dari mereka yang tidak mengerti dengan apa yang telah dilakukan Nenek moyangnya.

Tradisi merupakan tabiat kedua masyarakat, maksudnya setiap manusia mempunyai sifat bawaan, dan tradisi tersebut hampir sama sehingga sangat sulit untuk menghilangkan hal tersebut. Banyak para Kyai atau da'i berceramah, berjuang menghilangkan atau mengarahkannya ke jalan yang sesuai dengan syara' berbagai cara harus mereka tempuh, tetapi ada

5 Departemen Agama, al-Qur'an dan Terjemahannya. (Bandung: CV. Penerbit Diponegoro, 2004), hlm.796. 
kalanya tradisi sebagai medium pemersatu masyarakat. ${ }^{6}$ Penyambung tali silaturahim dari individu yang satu dengan lainnya, seperti tradisi nyareh dinah adalah sebagai penyambung hubungan antara masyarakat ke Kyai, atau murid pada gurunya, serta sesepuh yang ada dalam wilayah tersebut sebagai rasa penghormatan dalam tingkatan sosial.

Tradisi dalam masyarakat dilihat dari segi sebabnya ada dua diantaranya: pertama, tradisi qauly, yakni tradisi yang timbul dari suatu perkataan. Sebagai contoh dalam kebiasaan tidak menamakan ikan dengan daging. Kedua, tradisi 'amaly, yakni Tradisi yang timbul dari suatu perbuatan. Sebagai contoh dalam kebiasan jual beli dengan cara hanya memberi dan menerima barang tanpa mengucapkan sighat ijab dan qobul.

Tradisi dalam masyarakat dilihat dari segi praktiknya ada dua yakni: pertama, tradisi yang bersifat umum, yakni suatu hal yang telah menjadi kebiasaan segenap manusia dari setiap lapisan negeri dan derah tempat tinggalnya. Kedua Tradisi yang bersifat khusus yakni tradisi yang hanya berlaku dan tersebar dalam sebuah daerah tertentu, atau sebagian kelompok masyarakat tertentu, seperti Tradisi bagi kalangan pedagang atau petani. ${ }^{7}$

Dilihat dari segi ketentuan hukumnya ada dua yakni: pertama, tradisi yang bersifat shahih, artinya tradisi tersebut telah menjadi kebiasaan manusia secara turun temurun akan tetapi tidak menyalahi dalil syara', tidak menghalalkan yang haram dan tidak membatalkan yang wajib. Kedua, tradisi yang bersifat fasid, artinya tradisi tersebut telah menjadi kebiasaan manusia secara turun temurun akan tetapi hal tersebut menyalahi syara'

\footnotetext{
6 Rohimin, dkk., Harmonisasi Agama dan Budaya di Indonesia; Balai Penelitian dan Pengembangan Agama (Jakarta: PT. Nusantara Lestari. 2009), hlm.16.

7 Yusuf al-Qardlâwî, Keluasan Dan Keluwesan Hukum Islam, (Semarang: Dina Utama, 1993), hlm. 19.
} 
misalnya menghalalkan yang haram dan membatalkan yang wajib. ${ }^{8}$

\section{Kehujjahan Tradisi}

Hukum tradisi berbeda dengan hukum Fiqih, dalam hukum fiqih harus diucapkan rumus ijab qabul, persetujuan dapat dianggap ada sekaligus secara diam-diam atau sebagai kesimpulan dari sejumlah sikap, tingkah laku atau perbuatan kedua belah pihak. Para Fuqaha' dengan madzhab yang berbeda-beda berpendapat bahwa tradisi merupakan salah satu pertimbangan dalam mengambil ketentuan hukum menjadikan adat atau tradisi sebagai sumber fiqih sebagaimana firman Allah dalam surat al-A'raf, Ayat 199 : Jadilah engkau pemaaf dan suruhlah orang mengerjakan yang makruf, serta berpalinglah daripada orang-orang yang bodoh. 9

Tradisi juga merupakan sumber hukum yang fleksible, yang dapat berubah dan berbeda di tempat yang satu dan yang lainnya, sebagaimana pendapat Abdurrahim bahwasanya dari segi kekuatan dan ketetapan hukumnya, tradisi atau Adat dapat berubah sesuai perubahan yang terjadi pada tradisi itu sendiri, misalnya pendapat Imam Syafi'i yang berbeda ketika di Mesir dan di Irak, 10 namun harus dalam batas tidak menentang alQur'an dan Hadits

Dalam hal ini menunjukkan bahwa segala tradisi atau kebiasaan yang dianggap baik oleh umat Islam adalah baik menurut Allah, karena apabila tidak melakukan tradisi maka akan menimbulkan kesulitan, sedangkan firman Allah dalam Al-Qur'an surat al-Hajj ayat 78: “Dan berjihadlah kamu pada jalan Allah dengan jihad yang sebenar-benarnya. Dia telah memilih kamu dan Dia sekali-kali tidak menjadikan untuk kamu dalam agama suatu

\footnotetext{
8 Miftahul Arifin, Usul Fiqh Kaidah-kaidah Penetapan Hukum Islam, (Surabaya: CV.Citra Media, 1997), hlm.147.

${ }_{9}^{9}$ Departemen Agama, Al-Qur'an dan Terjemahannya, hlm. 199.

10 Sudarsono, Pokok-pokok Hukum Islam, (tk.: Rineka cipta, tt.), hlm.35.
} 
kesempitan."11Maksud ayat ini segala sesuatu yang ditetapkan oleh tradisi sama dengan yang ditetapkan oleh dalil yang berupa nash Al-Qur'an dalam masalah-masalah yang tidak terdapat dalam nash untuk menyelesaikannya. Oleh karena itu, tradisi yang benar dan tidak bertentangan dengan hukum syara' wajib diperhatikan dalam menentukan hukum syara' dan keputusan perkara.

\section{Tradisi Sebagai Dalil Penetapan Hukum Islam}

Islam mengakui tradisi sebagai salah satu sumber hukum, namun hal tersebut harus dengan syarat yakni: pertama, tradisi tersebut tidak bertentangan dengan al-Qur'an atau Hadits, serta tidak menyalahi Ijma'. Namun tradisi berbeda dengan ijma', ijma' merupakan persetujuan diantara mujtahid, sedangkan tradisi adalah kebiasan yang ada dalam masyarakat dalam waktu yang lama, dan telah disepakati oleh masyarakat banyak. ${ }^{12}$ Kedua, tradisi tersebut berlaku umum dalam masyarakat, artinya tradisi yang dijalani benar-benar sudah menjadi landasan umum dalam keseharian di wilayah tersebut.

Tradisi bukanlah landasan yuridis dan perangkat metodologis otonom yang berfungsi menciptakan hukumhukum baru, akan tetapi tradisi merupakan pelengkap untuk menguatkan hukum-hukum syari'at dan juga harus dengan syarat tradisi yang menurut perspektif syari'at universal, serta tidak bertentangan dengan nash keagamaan yang tekstual.

Para fuqaha' dalam menetapkan tradisi sebagai Hukum Islam berlandasan pada firman Allah SWT: Jadilah engkau pemaaf dan suruhlah orang mengerjakan yang makruf, serta berpalinglah daripada orang-orang yang bodoh. ${ }^{13}$

\footnotetext{
11 Departemen Agama, Al-Qur'an dan Terjemahannya, hlm. 523.

12 Sudarsono, Pokok-pokok Hukum Islam, hlm, 35.

${ }^{13}$ Departemen Agama, Al-qur'an, hlm. 177.
} 
Jadi jelas bahwa tradisi yang mengandung nilai positif dapat diterima oleh Islam dan tradisi yang negatif tidak dapat ditolerir oleh Islam. Hal ini sesuai kaidah Fiqih yang berbunyi : Adat menjadi dasar hukum. ${ }^{14}$

\section{Pelaksanaan Nyare Dhina}

Pada dasarnya setiap hari adalah baik, namun dalam jumlah hari dalam satu minggu ada hari-hari yang dianggap istimewa oleh sebagian masyarakat. Dan dalam satu tahun ada bulan-bulan yang dinggap karomah, seperti bulan yang dianggap bulan penuh berkah yakni bulan Ramadlon, Dulhijjah serta bulan Syawal, sehingga ada baiknya dalam melaksanakan akad nikah melandaskan riwayat tersebut, seperti dalam sebuah riwayat yang dikisahkan oleh Sitti Aisyah R.A.: Rasulullah SAW mengawini aku pada bulan Syawal, dan mempergauliku pada bulan Syawal, maka siapa istri rosulullah yang lebih baik nasibnya dariku, karenanya sitti Aisyah menganjurkan kaum muslim untuk menggauli istrinya di bulan Syawal. ${ }^{15}$ Begitu juga pernikahan Rasulullah SAW dengan Saudah binti Zam'ah yang dilaksanakan pada bulan Syawal tahun kesepuluh dari kenabian. ${ }^{16}$

Dalam pelaksanaan hari perkawinan, ada dhina, baik hari atau bulan yang memang khusus dianjurkan untuk melaksanakan acara tersebut, misalnya mengikuti jejak Rasulullah SAW. Seperti apa yang telah diceritakan Siti Aisyah R.A. bahwasanya Rasulullah menikahiku bulan Syawal, dan menyetubuhiku bulan syawal, maka dari itu Siti Aisyah menganjurkan para suami untuk menggauli istri untuk pertama kalinya di bulan Syawal. ${ }^{17}$

Pada umumnya masyarakat mendatangi rumah Kiyai atau guru dari anak yang akan menikah tersebut untuk minta dicarikan hari yang baik pada bulan tersebut. Namun bagi

\footnotetext{
14 Musbikin, Qawấ'id al-Fiqhiyyah, (Jakarta: Raja Grafindo Persada, 2001), hlm. 30

15 Al-Kandahlâwî, Fadilah al-A'mâl, hlm. 575.

16 Ibid., hlm. 574

17 Fadli Bahri, ensiklopedi Muslim, (Jakarta: PT.Darul Falah, 2000), hlm.581.
} 
masyarakat yang sudah mengetahui bahwa tidak hanya dalam hari-hari tertentu terdapat kebaikan atau disunnahkan. Masyarakat menentukan waktu pernikahan tersebut jauh sebelumnya, sehingga acara tersebut benar-benar khidmat, terlaksana pada bulan yang baik dan hari yang baik. sebagaimana yang dianjurkan oleh para ulama, semisal dalam kitab Qurratul 'Uyun (meskipun bukan termasuk kitab mu'tabar, ed.) yang di sya'irkan oleh al-Hafidz Ibnu Hajar yang artinya sebagai berikut: "jauhilah tujuh dari dengan sempurna, jangan kamu memulai sesuatu dan jangan pergi. Janganlah kamu beli pakaian baru atau perhiasan. Dan jangan kamu kawinkan anak putri dan jangan menanam poho. Tanggal tiga, lima, lalu tiga belas. Tanggal-tanggal berikutnya adalah tanggal enam belas, pada tanggal dua puluh satu, takutlah akan keburukannya, demikian pula tanggal dua puluh empat, dan tanggal dua puluh lima. Tiap-tiap hari rabu akhir bulan saya mencegahmu terus menerus hari itu adalah naas.terangkat keterangan yang kami sampaikan dari lautan ilmu, tuanku Ali putra paman Al-Mustafa (Nabi Muhammad) pemimpin ummat (manusia) 18

Akad nikah merupakan acara yang sakral, karena acara tersebut merupakan acara menyatukan dua orang yang berbeda, baik jenis kelamin, sifat, tingkah laku, tabi'at, serta pandangan hidup kedepan. Maka dari itu dalam kebiasaan masyarakat dalam menentukan hari tersebut bervariasi, diantaranya: pertama buku primbon: kebiasaan dalam masyarakat untuk mempermudah mengetahui hari yang baik dengan berpedoman padanya. Setelah melakukan penghitungan jumlah hari dan pasaran dari suami serta istri, lalu ditemukan neptu dari tanggal lahir keduanya, Seperti halnya dengan tradisi Kejawen yang mana dalam tradisi tersebut banyak hitung-hitungan hari baik atau hari yang membawa keberuntungan atau hari yang tidak baik atau hari yang

18 Muhammad Fairûz Nadhir Amrullah, Terjemahan Qurratul 'Uyun, (Surabaya: Pustaka Media, t.t.) hlm. 44. 
membawa sial. ${ }^{19}$ Dalam sebuah riwayat Rasulullah didatangi sahabat yang ingin menikah, dan pada saat itu juga mereka meminta dinikahkan, maka segeralah Rasulullah memerintahkan untuk mempersiapkan maskawin. ${ }^{20}$ Berdasarkan hadits tersebut menunjukkan kebolehan melaksanakan pernikahan tanpa penentuan hari, karena kebaikan dan keburukan itu dari Allah.

Kedua ramalan pada era modern ini muncul banyak paranormal yang menguasai ilmu nujum yakni ilmu perbintangan yang dalam istilah maduranya adalah tokang tebbek. Misalnya dalam tanggal kelahiran 22 Juni sampai 22 Juli disebut dengan bintang cancer dimana dalam bulan tersebut seseorang diramal tidak baik dan tergesa-tergesa dalam segala urusannya dan akan disesali di kemudian hari, sehingga dianjurkan untuk membenahi dan banyak memerlukan waktu untuk evaluasi. ${ }^{21}$ Tradisi-tradisi ini jauh dari apa yang diajarkan Syari'at, cuma sebagian orang saja yang masih berpedoman terhadap asumsi tersebut, yakni orang yang minim akan ilmu Agama yang mereka miliki. Peramal yang memiliki keahlian dengan kekuatan supra natural atau indra keenam dapat berkomunikasi dengan mahluk ghaib (Jin) untuk membantu mempraktikkan profesi tersebut. Sudah jelas dalam Hadits Rasulullah yang diriwayatkan oleh Aisyah ra.: "Maka Rasulullah bersabda: "para dukun itu sebenarnya tidak tau apa apa, kemudian orang-orang itu bertanya lagi" ya Rosulallah terkadang mereka itu memberi tahukan sesuatu dan kemudian terbukti benar? Rosulullah SAW bersabda,"itu adalah ucapan benar dari langit yang diperoleh jin, kemudian ia membisikkan ketelinga manusia bagai koko'ayam, kemudian mereka mencampurkan dengan seratus kedustaan". 22

\footnotetext{
19 Ibid, hlm. 30.

20 Ibnu Hajar al-'Asqolânî, Bulûgh al-Marâm, hlm. 208.

21 Tabloid Genie, (Jakarta: Pranata Komunikasi Massa, 2006), (16 juli 2006), hlm. 39.

22 Subhan, Ringkasan Shahih Muslim II, (Jakarta: Pustaka azzam, 2003), hlm.216.
} 


\section{Pengaruh Dhina Dalam Perkawinan}

Dalam membina keluarga setiap orang tua atau wali menginginkan putra-putrinya menemukan kebaikan dalam kehidupan yang selanjutnya, berbagai daya dan upaya dipersiapkan untuk memperoleh hal yang baik, dalam primbon Jawa terdapat keterangan tentang apa yang akan terjadi, hal ini dikenal dengan ilmu titen seperti contoh: (1) Bilamana perkawinan dilangsungkan pada bulan Sya'ban maka akan berakibat akan memperoleh kebahagiaan. (2) Bilamana melangsungkan perkawinan di bulan Rajab maka akan berakibat memperoleh anak banyak (3) Bilamana anda melangsungkan perkawinan di bulan Rabi'ul Awwal maka akan berakibat mati salah satunya, dan seterusnya. ${ }^{23}$

Dengan maksud menghindari hari na'as bulan ditahun Alif yang tergolong dalam daftar dibawah ini: (1) Bulan Sura atau dikenal dengan bulan Muharrom, jika untuk perkawinan wataknya: bertengkar dan mengalami kerusakan. Jangan dilakukan!; (2) Bulan Mulud atau dikenal dengan bulan Robiul Awwal kalau untuk perkawinan wataknya: Mati salah satu (mati dalam arti luas). Jangan dilakukan!; (3) Bulan Pasa atau dikenal dengan bulan Ramadlon kalau untuk perkawinan wataknya: Celaka besar. Jangan dilakukan!; (4) Bulan Dulkaidah kalau untuk perkawinan wataknya : Banyak musuh dan sakitsakitan. Jangan dilakukan!; (5) Bulan Sapar atau dikenal dengan bulan Muharram kalau untuk perkawinan wataknya: kekurangan dan banyak hutang. Boleh dilakukan; (6) Bulan Bakdamulud atau dikenal dengan bulan Robi'ul Akhir kalau untuk kawin wataknya: selalu dicacat dan menjadi pergunjingan yang tidak baik. Boleh dilakukan; (7) Bulan Jumadilawal kalau untuk kawin wataknya sering kehilangan, kena tipu dan banyak musuh. Boleh dilakukan!; (8) Bulan

${ }^{23}$ Labib MZ, Mujarrobat, (Surabaya: Bintang Usaha Jaya, 2001), hlm. 144. 
Sawal kalau untuk Mantu wataknya: kekurangan dan banyak hutang. Boleh dilakukan. ${ }^{24}$

Sehingga dari delapan bulan yang tertera diatas mempunyai sisa empat bulan yang baik yakni: (1) Bulan Jumadil Awal wataknya: kaya harta benda dan kemuliaan; (2) bulan Rejeb wataknya: sejahtera dan selamat; (3) Bulan Ruwah wataknya: panjang umur, dan berkelimpahan; (4) Bulan Besar wataknya: penuh keberuntungan dan sukacita. ${ }^{25}$ Namun qadlo' dan qodar adalah mutlak dalam kuasa Allah, Allah sebagai penentu kebaikan dan keburukan tersebut yang akan terjadi pada hamba-hambanya, manusia hanya mencari dan berusaha untuk mendapatkannya. Sebagaimana firman Allah SWT dalam surat al-An'âm: Jika Allah menimpakan suatu kemudaratan kepadamu, maka tidak ada yang menghilangkannya melainkan Dia sendiri. Dan jika Dia mendatangkan kebaikan kepadamu, maka Dia Maha Kuasa atas tiap-tiap sesuatu26.

\section{Metode Penelitian}

Dalam proses perolehan data dan informasi yang lengkap mengenai penelitian tradisi nyare dina di Desa Larangan Badung Kecamatan Palengaan Kabupaten Pamekasan memerlukan pendekatan dan metode penelitian. Metode tersebut dipilih dengan pertimbangan kesesuaian dengan objek penelitian, maka dari itu penelitian ini menggunakan kualitatif. Menurut Bogdan dan Taylor sebagaimana dikutip oleh Lexy J Moleong bahwa pendekatan kualitatif merupakan proses penelitian yang menghasilkan data deskriptif yang berupa katakata tertulis atau lisan dan orang yang berperilaku dapat diamati. ${ }^{27}$

24 http://www.marsudilaras.org./index.php?option=com. diakses: tanggal 22 Juni 2012

25 Ibid.

26 Departemen Agama, Al-Qur'an dan Terjemahannya, hlm. 130.

27 Lexy J Moleong, Metodologi Penelitian Kualitatif, (Bandung: PT Remaja Rosda Karya, 2007), hlm. 4. 
Dalam pendekatan ini cenderung berdasarkan pada usaha mengungkapkan dan memformulasikan data lapangan dalam bentuk kata-kata serta menggambarkan realitas aslinya untuk kemudian data tersebut dianalisis dan diabsrtaksikan dalam bentuk teori sebagai tujuan final. Peneliti tertarik dengan penelitian kualitatif sebab peneliti ingin mengetahui fenomena yang berkembang sebagai kesatuan yang diketahui secara utuh tanpa terikat oleh suatu variabel atau hipotesis tertentu. Apabila membicarakan jenis penelitian, maka hal tersebut bergantung dari sudut apa seseorang melihatnya. Dilihat dari sudut sifatnya, dikenal dengan adanya penelitian eksploratoris, penelitian deskriptif dan penelitian eksplanatoris. ${ }^{28}$

Metode yang digunakan dalam penelitian ini adalah kualitatif deskriptif, yang mana peneliti mempunyai keinginan untuk mengetahui berdasarkan data emperis. Dengan metode penelitian ini, tentu dapat memudahkan peneliti agar lebih dekat dengan subjek yang sedang diteliti oleh peneliti dan lebih peka terhadap pengaruh berbagai fenomena yang terjadi di lapangan. Dalam hal ini peneliti ingin menggambarkan tradisi nyare dhina di Desa Larangan Badung Kecamatan Palengaan Kabupaten Pamekasan dalam Perspektif Hukum Islam.

\section{Temuan Peneliti}

Akad nikah mempunyai beberapa rukun dan syarat yang harus dipenuhi. Rukun dan syarat menentukan hukum suatu perbuatan, terutama menyangkut dengan sah atau tidaknya perbuatan tersebut dari segi hukum. Kedua kata tersebut mengandung arti yang sama dalam hal bahwa keduanya merupakan sesuatu yang harus diadakan. Dalam pernikahan misalnya, rukun dan syarat tidak boleh tertinggal. Artinya, pernikahan tidak sah bila keduanya tidak ada atau tidak lengkap.

\footnotetext{
28 Soerjono Soekanto, Pengantar Penelitian Hukum, (Jakarta: Universitas Indonesia Press, 2005), hlm. 9.
} 
Dari hasil Observasi yang dilakukan peneliti, kebiasaan masyarakat Larangan Badung melaksanakan akad nikah bersamaan dengan walimah sehingga banyak disaksikan oleh para undangan yang hadir saat itu. Dan yang mengawinkan (taukil wali nikah, ed.) adalah Kyai dari pondok atau guru ngaji dari pihak mempelai wanita yang kawin tersebut, akan tetapi pencatatan dilakukan oleh Pihak KUA pada saat itu juga.

Dari hasil wawancara yang peneliti lakukan di Desa Larangan Badung Palengaan Pamekasan ditemukan praktek nyare dhina yang masih dilestarikan. Apa yang menjadi faktor tradisi nyare dhina tetap dilakukan oleh masyarakat? serta bagaimana tradisi nyare dhina dalam pandangan Hukum Islam?

Maka dari hasil wawancara tersebut, peneliti akan menyimpulkan hasil temuan tersebut sebagai berikut: Keberadaan tradisi nyare dhina merupakan kebiasaan turun temurun dilaksanakan dengan mendatangi kyai atau guru ngaji dimana proses nyare dhina lebih banyak dilakukan oleh pihak keluarga calon pengantin wanita.

Faktor yang mempengaruhi adanya tradisi nyare dhina adalah pertama, adanya jalinan silaturrahim antara Kyai dan masyarakat atau guru dan santrinya yang merupakan pendorong tradisi nyare dhina. Kedua, harapan agar Kyai atau guru mendoakan kedua calon pengantin. Adanya tradisi nyare dhina yang terdapat dalam kehidupan masyarakat merupakan peninggalan sesepuh yang pada awalnya menggunakan Primbon dan penghitungan angka kelahiran dari kalender jawa serta yang mengetahui metode tersebut sesepuh atau dukun. Namun dengan perkembangan zaman serta pemahaman masyarakat terhadap ajaran Islam, kebiasaan tersebut berubah, Kyai atau Guru ngaji yang a'lim menjadi rujukan masyarakat.

Ada bulan yang menjadi kebiasaan masyarakat Larangan Badung dalam melaksanakan perkawinan, yakni Syawal, Sya'ban, Rajab dan Bulan Dzulhijjah, Sesuai dengan pendapat 'Ulama' tentang Asyhur al-Hurum (bulan yang di mulyakan) 
meliputi bulan Muharram, Dzulhijjah, Dzulqaidah, dan Rajab. ${ }^{29}$ Serta hari Jum'at dan Kamis yang sering menjadi pilihan masyarakat Larangan Badung, dengan tujuan mencari berkah pada waktu tersebut. Mereka merujuk pada Hadist yang diriwayatkan oleh Abi Hurairah : Hari yang terbaik dimana setiap kali matahari terbit adalah hari jumat, pada hari jumat adam diciptakan dan pada hari itu juga di masukkan kedalamnya, serta tidak terjadi kiamat kecuali hari jumat. ${ }^{30}$

Karena pernikahan merupakan pemersatuan dua orang, yakni menjadi sebuah keluarga yang akan dijalani bersama, dalam pelaksanaan nyare dhina yang menjadi kebiasaan masyarakat Larangan Badung adalah pihak keluarga mempelai wanita, karena merupakan pelaksana inti dari perkawinan tersebut. Tentang Faktor Pengaruh Adanya tradisi nyare dhina yang menjadi kebiasaan masyarakat Larangan Badung.

Para orang tua yang memiliki putra putri yang ingin kawin akan mempersiapkan sematang dan semaksimal mungkin, seluruh rangkaian acara mulai dari pinangan sampai saat-saat bulan madu, termasuk mempersiapkan bulan serta tanggal yang baik untuk melaksanakan akad nikah. Misalnya dengan menentukan hari sesuai dengan pernikahan Nabi dengan Siti Aisyah dan Saudah yang dilaksanakan pada bulan Syawal : Rasulullah SAW mengawini aku pada bulan Syawal, dan mempergauliku pada bulan Syawal, maka siapa istri rosulullah yang lebih baik nasibnya dariku, karenanya sitti Aisyah menganjurkan kaum muslim untuk menggauli istrinya di bulan Syawal. 31

Pelaksanaan acara perkawinan yang menjadi kebiasaan masyarakat Larangan Badung pada umumnya semarak, sehingga harus banyak melibatkan sanak keluarga serta para tetangga, dan acara akad nikah bersamaan dengan Walimah. Sehingga sangat besar harapan dalam pelaksanaan itu

${ }^{29}$ M. Maskur Khoir, Hidayah, (Kediri: Duta Karya Mandiri.tt.), hlm. 30.

30 Abu Dawud, Sahih Sunan Abu Dawud, pent. Arief Tajuddin (Jakarta: Pustaka Azzam, 1998), hlm. 400.

31 Rohimin,dkk., Harmonisasi Agama dan Budaya di Indonesia, hlm. 16. 
berlangsung khidmat dan penuh berkah sehingga direncanakan untuk dilaksanakan dibulan serta hari yang baik. Yang umumnya masyarakat Larangan Badung mendatangani Kyai, dengan tujuan silaturrahim pada Kyai atau guru ngaji yang tujuannya dicarikan hari yang baik serta didoakan akan langgeng serta mendapat berkah, hal tersebut yang menjadi pendorong masyarakat untuk selalu melaksanakan tradisi nyare dhina.

Sedangkan pandangan Hukum Islam terhadap tradisi nyare dhina yang menjadi kebiasaan masyarakat Larangan Badung adalah sebagai berikut: Pertama, jika ditinjau dari segi sebabnya, tradisi nyare dhina termasuk tradisi 'amali, yakni tradisi yang timbul dari suatu perbuatan, tradisi yang dimaksud adalah perbuatan dari nenek moyang yang dilakukan secara turun temurun dari generasi ke generasi, meskipun pada mulanya tradisi tersebut pada zaman dulu dipraktekan dengan hal yang tidak sesuai dengan ajaran Islam, namun sekarang tradisi yang sama tapi praktek yang berbeda yakni dengan arahan positif yang tidak menyalahi aturan-aturan yang ditetapkan oleh syari'at Islam. Kedua, jika ditinjau dari segi orang yang melakukan tradisi nyare dhina termasuk tradisi khusus, yakni tradisi yang berlaku dalam satu wilayah tertentu saja, artinya dalam pelaksanaan tradisi tersebut tidak merata dalam melaksanakan tradisi nyare dhina tersebut, meskipun ada kesamaan nama tradisi namun belum tentu dalam prakteknya sama pula.

Ketiga, ditinjau dari segi ketentuan hukumnya tradisi nyare dhina yang terdapat dalam desa Larangan Badung ternasuk tradisi Shahih, tidak menyalahi nas, tidak menghilangkan maslahat, dan tidak menimbulkan mafsadat, dalam pelaksanaan tradisi merupakan do'a yang digambarkan dengan tindakan, yakni mencari ridlo Allah. ${ }^{32}$

32 Yusuf al-Qardlâwî, Keluasan Dan Keluwesan Hukum Islam, hlm.19 
Berdasarkan paparan diatas dapat disimpulkan bahwa Nyare dhina merupakan hal yang sudah biasa dilakukan dalam persiapan pernikahan, dan anggapan mereka nyare dhina merupakan media mengharap berkah Allah dalam pelaksanaan dihari yang baik. tradisi nyare dhina perlu dilestarikan dan dilakukan selama tidak bertentangan dan tidak menyimpang serta tidak menyalahi aturan norma-norma agama serta mendukung pada kemaslahatan masyarakat. Oleh karenya hukum tradisi nyare dhina adalah mubah yang dalam pelaksanannya menuju pada hal yang bersifat positif serta tidak ada unsur syirik.

\section{Penutup}

Berdasarkan urain di atas, maka penyusun dapat mengambil kesimpulan sebagai berikut : pertama Kebiasaan masyarakat Di Desa Larangan Badung Kecamata Palengaan Kabupaten Pamekasan dalam menentukan hari akad nikah atau dalam istilah Madura dikenal dengan Nyare Dhina masih dilestarikan oleh masyarakat sekitar. Meskipun tidak semua masyarakat yang ada dalam Desa Larangan Badung mengetahui apa yang sebenarnya tujuan serta dampak terhadap perkawinan yang akan di laksanakan. Kedua, tradisi nyare dhina merupakan sebuah penyambung Silaturrahim (nyabis) dari masyarakat pada Kyai sebagai tokoh yang paling berpengaruh dan disegani dalam kehidupan sosial. Ketiga, tradisi nyare dhina dalam menentukan hari perkawinan merupakan perbuatan yang mubah, mengerjakannya bukan sesuatu yang dilarang oleh agama.

\section{Daftar Pustaka:}

Al-'Asqalânî, Ibnu Hajar. Bulûgh al-Marâm. Surabaya: Nurul Hidayah, tt.

al-Kandahlâwî, Maulana Muhammad Zakariya. Fadilah al$A^{\prime} m a ̂ l$, terj. Musthafa Sayani. Bandung: Pustaka Ramadhan, tt. 
al-Qardlâwî, Yusuf. Keluasan Dan Keluwesan Hukum Islam. Semarang: Dina Utama, 1993.

Arifin, Miftahul. Usul Figh Kaidah-Kaidah Penetapan Hukum Islam. Surabaya: Citra Media, 1997.

Bahri, Fadli. Ensiklopedi Muslim. Jakarta: PT.Darul Falah, 2000.

Departemen Agama. al-Qur'an dan Terjemahannya. Bandung: CV. Penerbit Diponegoro, 2004.

http:/ / www.marsudilaras.org./index.php?option=com.

Khoir, M. Maskur. Hidayah. Kediri: Duta Karya Mandiri, tt.

Labib Mz. Mujarrobat. Surabaya: Bintang Usaha Jaya, 2001.

Musbikin. Qawấ'id al-fiqhiyyah. Jakarta: Raja Grafindo Persada. 2001.

Moleong, Lexy J. Metodelogi Penelitian Kualitatif. Bandung: PT Remaja rosda Karya, 2007.

Nadhir, Muhammad Fairûz Amrullah. Terjemahan Qurratul 'Uyun. Surabaya: Pustaka Media, tt.

Rohimin dkk. Harmonisasi Agama dan Budaya di Indonesia. Jakarta: Balai Penelitian dan Pengembangan Agama. 2009.

Subhan. Ringkasan Shahih Muslim II. Jakarta: Pustaka azzam. 2003.

Sudarsono. Pokok-pokok Hukum Islam. tk.: Rineka cipta, tt.

Soekanto, Soerjono. Pengantar Penelitian Hukum. Jakarta: Universitas Indonesia Press. 2005.

Abu Dawud, Sahih Sunan Abu Dawud, pent. Arief Tajuddin. Jakarta: Pustaka Azzam. 1998.

Tabloid Genie. Jakarta: Pranata Komunikasi Massa. 2006. 